\title{
Penentuan Top Brand Menggunakan Social Network Analysis pada E-Commerce Bukalapak dan Tokopedia
}

\author{
Wildan Ignatio $^{1}$, Muhammad Rizqy Dwi Putra ${ }^{2}$, Made Kevin Bratawisnu ${ }^{3}$ \\ ${ }^{1}$ Program Studi Teknik Telekomunikasi, Universitas Telkom \\ ${ }^{2,3}$ Program Studi Manajemen Bisnis Telekomunikasi dan Informatika, Universitas Telkom \\ 1wildanignatio67@gmail.com \\ 2rizqydwip@gmail.com \\ 3madekevinbratawisnu@gmail.com
}

\begin{abstract}
Abstrak - Perkembangan internet di Indonesia meningkat pesat sehingga hal ini mendorong pula perkembangan media sosial di Indonesia. Bisnis e-commerce dapat memanfaatkan perkembangan media sosial untuk strategi pemasaran yang dilakukan dan penyebaran informasi secara online. Media sosial yang umum digunakan oleh masyarakat Indonesia adalah Twitter. Pada media sosial Twitter, user mengungkapkan informasi yang diketahui terkait suatu brand. Hal ini membuktikan tingkat awareness user tersebut terhadap suatu brand. Informasi tersebut merupakan User Generated Content (UGC) yaitu jejak rekam yang ditinggalkan user di media sosial. Penelitian ini memanfaatkan fenomena tersebut untuk mengukur peringkat brand dalam upaya mengukur kesadaran seseorang akan suatu brand. Metode yang digunakan adalah Social Network Analysis (SNA) yaitu metode untuk memolakan user yang berkomunikasi di media sosial. Pemanfaatan analisis aktor di media sosial dengan menggunakan SNA membantu perusahaan dalam menilai posisi perusahaan berdasarkan tingkat awareness masyarakat di media sosial terkait brand perusahaan. Bisnis e-commerce merupakan bisnis yang muncul dikarenakan perkembangan teknologi dan aktif dalam mempromosikan kegiatan pemasaran di media social. Jenis $e$ commerce yang aktif melakukan kegiatan engagement adalah $e$ commerce C2C (Consumer to Consumer) yaitu Bukalapak dan Tokopedia. Sehingga penelitian ini akan menentukan top brand diantara kedua e-commerce tersebut. Penelitian ini menggunakan metode SNA, dengan data sekunder berupa tweets konsumen di Twitter terkait Bukalapak dan Tokopedia. Jenis penelitian adalah penelitian kualitatif yaitu penelitian yang bertujuan untuk mendeskripsikan suatu hasil dari fenomena yang terjadi. Hasil dari penelitian ini adalah peringkat brand $e$ commerce berdasarkan tingkat awareness user di media sosial.
\end{abstract}

Kata Kunci- : Social Network Analysis; Media Sosial; User Generated Content; Brand

\section{Pendahuluan}

Kemajuan teknologi informasi telah membawa peluang bagi bisnis untuk mengembangkan bisnisnya. Dengan adanya teknologi informasi pada bisnis membuat keunggulan melalui pemanfataan layanan internet. Saat ini, Indonesia mengalami pertumbuhan pengguna internet yang sangat pesat. Berdasarkan data dari We Are Social pada awal tahun 2017 bahwa dari 250 juta penduduk di Indonesia, tercatat ada sekitar 88 juta adalah pengguna aktif internet dan 74 juta merupakan pengguna media sosial aktif [1].

Perkembangan teknologi internet tersebut didampingi dengan adanya perkembangan pada bisnis e-commerce. Bisnis online e-commerce merupakan sarana transaksi komersial antara dan antar organisasi dan perorangan secara digital dengan pemanfaatan internet, web dan aplikasi bisnis online [2]. Dari survei yang dilakukan badan survei telematika, We Are Social bahwa terjadi peningkatan sebesar $12 \%$ menjadi 24,74 juta pengguna internet yang berbelanja secara online melalui e-commerce [1].

Konsumen Indonesia mulai mengadopsi budaya belanja online disebabkan pula karena munculnya berbagai bisnis $e$ commerce di Indonesia. Berbagai jenis e-commerce terdapat di Indonesia, salah satunya adalah bisnis e-commerce $\mathrm{C} 2 \mathrm{C}$ (Consumer to Consumer). Bisnis e-commerce $\mathrm{C} 2 \mathrm{C}$ merupakan bisnis online dengan user (pengguna) yang dapat berjualan di marketplace tersebut sehingga user dapat menjadi penjual ataupun pembeli. Berdasarkan survei konvensional yang dilakukan oleh topbizz pada tahun 2016 dalam Sharing Vision bahwa e-commerce $\mathrm{C} 2 \mathrm{C}$ yang memiliki tingkat awareness tertinggi adalah Tokopedia dengan nilai 45,2 dan Bukalapak dengan nilai 36,9 [3].

Bisnis e-commerce dapat memanfaatkan fenomena perkembangan pengguna media sosial di Indonesia. Hal ini dapat digunakan oleh perusahaan bisnis e-commerce untuk menilai posisi mereka dibandingkan pesaing di media sosial. Perusahaan bisnis e-commerce perlu memahami fungsi media sosial dalam bisnis [4]. Hal ini disebabkan media sosial telah menjadi salah satu aspek kehidupan yang besar dalam masyarakat [5].

Percakapan yang ditulis di media sosial oleh para pengguna disebut User Generated Content (UGC). UGC bahwa data yang di-posting oleh pengguna dan bisa dilihat secara umum oleh pengguna lain [6]. Pengguna tersebut mencakup pengguna individu maupun pengguna yang merupakan perusahaan-perusahaan dari berbagai sektor. Sebagai salah satu media sosial yang paling banyak digunakan, Twitter memproduksi data dalam jumlah yang cukup besar setiap harinya. Para pengguna menggunakannya untuk berkomentar tentang produk dan jasa dari suatu perusahaan.

Media sosial Twitter menyimpan banyak data berharga yang harus dimanfaatkan perusahaan [4]. Twitter merupakan media sosial personal yang dapat dijadikan sebagai kanal promosi yang potensial untuk mendatangkan pembeli, sehingga perusahaan perlu melakukan analisis yang mendalam terkait media sosial [5]. Salah satu metode yang dapat digunakan adalah dengan melakukan analisis top brand menggunakan properti jaringan pada Social Network Analysis (SNA). 
Analisis top brand dengan menggunakan properti jaringan pada SNA merupakan salah satu alternatif yang murah dan lebih real time dalam menganalisis posisi brand di mata konsumen. Top brand konvensional yang dilakukan oleh Frointier Consulting Group membutuhkan waktu yang lama dan membutuhkan biaya yang besar untuk melakukan kuisioner dan wawancara terkait posisi brand tersebut. Sehingga diperlukan metode baru yang lebih real time dan lebih murah yaitu dengan menganalisis media sosial. Dikarenakan pada media sosial terdapat banyak data UGC yang diutarakan user mengenai suatu brand sehingga menjadi data yang berharga bagi perusahaan.

Metode analisis untuk alternatif top brand adalah dengan melihat properti jaringan pada SNA. SNA dapat dideskripsikan sebagai suatu ilmu yang mempelajari hubungan manusia dengan bantuan teori graf sehingga dapat memolakan hubungan yang terjadi antar user di media sosial sehingga membantu perusahaan dalam menganalisis media sosial [7]. Untuk menilai top brand menggunakan SNA dapat dilihat melalui properti jaringan pada SNA. Properti pada jaringan dapat memperlihatkan hubungan antara bisnis $e-$ commerce dengan user yang membicarakan e-commerce tersebut di media sosial, sehingga dapat dinilai keaktifan dan tingkat awareness user mengenai e-commerce yang dibicarakan di media sosial.

Melihat pentingnya analisis yang harus dilakukan bisnis $e$ commerce di media sosial serta media sosial dapat memberikan analisa top brand yang lebih murah dan real time sehingga penulis mengajukan judul penelitian yaitu "Penentuan Top Brand Menggunakan Social Network Analysis pada e-commerce Tokopedia dan Bukalapak".

\section{TINJAUAN PUSTAKA}

\section{A. Big Data}

Big data pada dasarnya berarti dataset yang terlalu besar untuk diproses oleh sistem tradisional, sehingga diperlukan teknologi baru untuk memproses data tersebut. Teknologi big data seringkali digunakan untuk mendukung pemrosesan data dalam teknik data mining dan aktivitas lainnya [6]. Big data adalah data yang melebihi kapasitas pemrosesan sistem database konvensional. Big data memiliki tiga karakterisitk utama atau biasa disebut dengan $3 \mathrm{~V}$ yaitu Volume atau ukuran yang sangat besar, Velocity yaitu bergerak dengan cepat, dan Variety yaitu memiliki keberagaman data atau variasi dalam informasi [8]. Sehingga tidak sesuai dengan arsitektur database konvensional.

Dengan mengadopsi teknologi analisis yang canggih dan teknik yang tepat, organisasi dapat menggunakan big data untuk mengembangkan wawasan, produk, dan layanan inovatif yang dapat meningkatkan nilai ekonomi dari organisasi melalui big data tersebut [9]. Salah satu big data yang tersebar dan dapat diperoleh dengan mudah adalah data yang terdapat pada media sosial. Dampak dari big data di media sosial memunculkan big social data yang dapat dianalisis untuk menghasilkan informasi mengenai perilaku online dari seseorang, sehingga organisasi bisnis dapat memprediksi apa yang akan mereka lakukan selanjutnya dan apa yang akan mereka beli.

\section{B. User Generated Content (UGC)}

Definisi dari User Generated Content sendiri adalah data atau konten yang secara umum dapat dilihat oleh user lain, dimana konten tersebut berisi sejumlah kreatifitas dan dibuat oleh orang-orang yang bukan merupakan profesional dalam hal tersebut [6]. Sehingga mining UGC berarti melakukan proses untuk menemukan pola atau informasi pada suatu konten yang dibuat oleh user. Adapun yang juga termasuk dalam UGC adalah blog, wiki, forum diskusi, post, chat, tweet, podcast, pin, digital image, video, audio, dan berbagai bentuk media lain yang diciptakan oleh user online yang dapat diakses melalui web atau media sosial [6].

\section{Social Network Analysis (SNA)}

Social Network Analysis (SNA) dapat dideskripsikan sebagai suatu ilmu yang mempelajari hubungan manusia dengan bantuan teori graf [7]. SNA mempelajari struktur hubungan yang mengaitkan individu atau unit sosial lain dan ketergantungan dalam perilaku atau sikap yang berhubungan dengan susunan hubungan sosial. Hubungan tersebut digambarkan dengan nodes, atau bisa disebut vertices yang melambangkan aktor atau user dan ties atau disebut juga edges, links atau connections yang melambangkan hubungan antar aktor [10].

Terdapat lima properti jaringan dalam jejaring sosial [11], antara lain:

TABEL I

PROPERTI JARINGAN SNA

\begin{tabular}{|c|c|}
\hline $\begin{array}{l}\text { Properti } \\
\text { Jaringan }\end{array}$ & Pengertian \\
\hline Size & $\begin{array}{l}\text { Menunjukkan jumlah node dalam suatu jaringan } \\
\text { yang melambangkan banyak user yang } \\
\text { berinteraksi dan menunjukkan pula jumlah edges } \\
\text { yang melambangkan banyak hubungan yang } \\
\text { terjadi pada jaringan sosial tersebut. }\end{array}$ \\
\hline Modularity & $\begin{array}{l}\text { Menunjukkan bagaimana hubungan yang ada } \\
\text { pada jaringan sosial dapat membentuk kelompok } \\
\text { yang berbeda-beda dalam suatu jaringan sosial. }\end{array}$ \\
\hline Diameter & $\begin{array}{l}\text { Jalur terdekat maksimal dalam suatu network } \\
\text { atau bisa disebut jarak terbesar antara sepasang } \\
\text { node. }\end{array}$ \\
\hline $\begin{array}{l}\text { Average } \\
\text { Degree }\end{array}$ & $\begin{array}{l}\text { Menunjukkan jumlah rata-rata hubungan yang } \\
\text { dimiliki oleh aktor (nodes) pada suatu jaringan } \\
\text { sosial. }\end{array}$ \\
\hline $\begin{array}{c}\text { Average } \\
\text { Path Length }\end{array}$ & $\begin{array}{l}\text { Jarak rata-rata antara satu node dengan node } \\
\text { yang lain dalam suatu network. }\end{array}$ \\
\hline
\end{tabular}

\section{Brand}

Definisi brand adalah nama, istilah, tanda lambang, desain atau kombinasi untuk mengidentifikasi barang atau jasa dari salah satu penjual atau kelompok penjual dan mendiferensiasikan mereka dari para pesaing [12].

Penentuan brand sudah ada selama berabad-abad yang menjadi sarana untuk membedakan suatu barang atau produk 
yang dihasilkan oleh satu perusahaan dengan perusahaan lainnya. Saat ini brand memegang peranan cukup penting bagi suatu perusahaan yang dapat mempengaruhi nilai perusahaan dan dapat mempengaruhi konsumen untuk menentukan pilihan pada perusahaan tersebut.

\section{Metode PENELITIAN}

Penelitian ini termasuk jenis penelitian deskriptif. Penelitian deskriptif adalah penelitian yang bertujuan untuk mendeskripsikan karakteristik dari suatu objek, orang, grup, organisasi atau lingkungan yang menggambarkan situasi atau kejadian tertentu [12]. Selain itu penelitian ini termasuk ke dalam penelitian kualitatif. Penelitian dalam pendekatan kualitatif sering digunakan untuk melihat lebih dalam suatu fenomena sosial termasuk di dalamnya kajian terhadap ilmu pendidikan, manajemen dan administrasi bisnis, kebijakan publik, pembangunan ataupun ilmu hukum [12].

Sedangkan metode yang digunakan dalam penelitian ini adalah Social Network Analysis (SNA). Secara sederhana, SNA dapat disebut sebagai sebuah studi yang mempelajari tentang hubungan antar manusia yang digambarkan dalam bentuk graf [7]. SNA menggambarkan hubungan sosial dalam teori network yang terdiri atas nodes dan ties (atau disebut juga edges, links atau connections) dimana nodes adalah aktor/individu dalam suatu network dan ties adalah hubungan antar aktor (Passmore, 2011). Adapun tahapan dalam penelitian ini dapat dilihat pada Gambar 1.

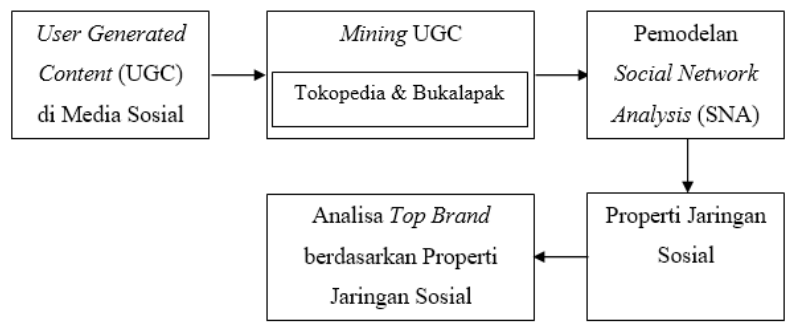

Gbr. 1 Tahapan Penelitian

Konten yang dibuat di user di media sosial yang bersifat terbuka dan dapat diakses oleh banyak orang dapat dikatakan sebagai UGC, sesuai dengan definisi oleh Moens, Li, \& Chua (2014). Berdasarkan penelitian sebelumnya yang dilakukan oleh Olmedilla, M., et al. (2016:79) bahwa data UGC online memainkan peran yang penting sebagai sumber informasi bagi organisasi untuk mencari penggalian nilai, sehingga perusahaan harus dapat mengelola data UGC yang berukuran besar (big data) sebagai intelijen bisnis.

Selanjutnya dilakukan pengambilan data UGC atau disebut juga Mining UGC pada media sosial. Mining UGC menggunakan aplikasi R Studio untuk melakukan crawling tweets yang mengandung keyword "tokopedia" dan "bukalapak". Hasil crawling tweets dilakukan pre-processing data untuk menghilangkan tweet yang tidak relevan agar lebih mudah untuk dilakukan proses analisis. Selanjutnya menentukan aktor yang berinteraksi pada setiap tweet untuk dijadikan sebagai node dalam social network.

Setelah pre-processing data maka dilakukan pemodelan jaringan sosial dengan metode SNA. Visualisasi jaringan dilakukan dengan aplikasi Gephi sehingga akan terlihat nodes yang melambangkan aktor dan edges yang melambangkan hubungan antar aktor dalam jaringan sosial. Dalam jaringan sosial yang telah dimodelkan maka dapat dilihat properti jaringan sosial untuk membandingkan jaringan sosial antar bisnis.

Properti jaringan sosial yang dianalisis antara lain: size, modularity, diameter, average degree, average path length dan clustering coefficient. Size menunjukkan besarnya jaringan sosial, hal ini dapat menjadi business intelligence mengenai jumlah aktor yang melakukan interaksi dan jumlah interaksi yang terbentuk sehingga bisnis e-commerce mengetahui tingkat awareness user terkait brand mereka. Modularity menunjukkan kelompok yang terbentuk mengenai percakapan di media sosial. Diameter menunjukkan jarak hubungan antar aktor yang berinterkasi, jika semakin dekat maka semakin baik dikarenakan hubungan aktor yang membicarakan brand tersebut semakin baik. Average degree menjelaskan mengenai rata-rata hubungan pada jaringan sosial. Average path length menandakan jumlah rata-rata akun user yang harus dilewati user tertentu untuk berinteraksi.

Hasil perbandingan properti jaringan tersebut dapat dijadikan salah satu alternatif untuk analisa top brand bisnis ecommerce di media sosial berdasarkan properti jaringan yang terjadi yang melambanngkan tingkat kesadaran aktor terkait brand e-commerce.

\section{HASIL DAN PEMBAHASAN}

\section{A. Hasil Crawling Data}

Crawling data dilakukan di media sosial Twitter selama 1 minggu yaitu pada tanggal 16 Oktober 2017 - 23 Oktober 2017 dengan menggunakan aplikasi pemrogaman R Studio. Hasil tweets yang berhasil di crawling, yaitu:

TABEL III

HASIL CRAWLING DATA

\begin{tabular}{|c|l|}
\hline Nama e-commerce & Hasil Crawling Tweets \\
\hline Bukalapak & 21265 tweets \\
\hline Tokopedia & 6768 tweets \\
\hline
\end{tabular}

Dapat dilihat pada Tabel II, bahwa tweets yang telah dicrawling terhadap interaksi user di sosial media Twitter mengenai e-commerce Tokopedia Bukalapak sebanyak 21265 tweets, sedangkan tweets terhadap interaksi user di sosial media Twitter mengenai e-commerce Tokopedia sebanyak 6768 tweets selama periode pengambilan data.

\section{B. Jaringan Sosial Bukalapak}


Hasil pemodelan jaringan sosial percakapan user mengenal Bukalapak dapat dilihat pada Gambar 2 berikut:

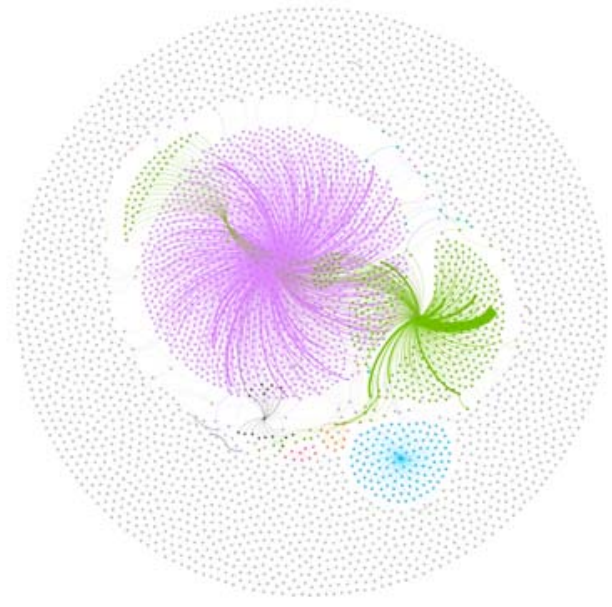

Gbr. 2 Jaringan Sosial Bukalapak

Hasil pemodelan yang menggambarkan jaringan sosial yang terbentuk dari interaksi user mengenai Bukalapak dapat dilihat pada Gambar 2. Terlihat pada gambar node (titik) yang melambangkan aktor dan edge (garis) yang melambangkan hubungan antar aktor. Setelah melakukan pemodelan pada jaringan sosial, maka dilakukan analisis properti jaringan tersebut untuk mengetahui nilai dari jaringan sosial.

TABEL IIIII

HASIL PROPERTI JARINGAN SOSIAL BUKALAPAK

\begin{tabular}{|c|l|l|}
\hline No & \multicolumn{1}{|c|}{ Properti Jaringan } & \multicolumn{1}{c|}{ Hasil } \\
\hline 1 & Size & $\begin{array}{l}\text { Nodes: } 4040 \\
\text { Edges: } 2203\end{array}$ \\
\hline 2 & Modularity & 0,466 \\
\hline 3 & Diameter & 10 \\
\hline 4 & Average Degree & 1,091 \\
\hline 5 & Average Path Length & 2,999 \\
\hline
\end{tabular}

Pada Tabel III, dapat dilakukan penilaian terkait jaringan sosial yang terbentuk mengenai Bukalapak. Size menunjukkan jumlah komponen dalam system. Size pada jaringan social Bukalapak memiliki 4040 actor dan 2203 hubungan antar actor. Modularity menunjukkan bagaimana actor dapat membentuk kelompok yang berbeda-beda dalam suatu jaringan. Nilai modularity pada jaringan social Bukalapak adalah 0,466. Diameter adalah jarak terdekat antara 2 nodes terjauh. Nilai diameter jaringan social Bukalapak adalah 10 sehingga jarak terdekat antara 2 actor terjauh pada jaringan social Bukalapak sebesar 10. Average degree menunjukkan derajat rata-rata dari jumlah link yang menghubungkan satu node dengan node lainnya. Nilai average degree pada jaringan social Bukalapak sebesar 1,091. Average path length diterjemahkan sebagai jumlah rata-rata akun atau node yang harus dilewati oleh suatu akun untuk mencapai akun tertentu. Nilai average path length pada jaringan sosial Bukalapak adalah 2,999.

\section{Jaringan Sosial Tokopedia}

Setelah melewati pre-processing data dan pemodelan network, maka didapatkan hasil jaringan sosial mengenai Tokopedia di media sosial Twitter yang dapat dilihat pada Gambar 3.

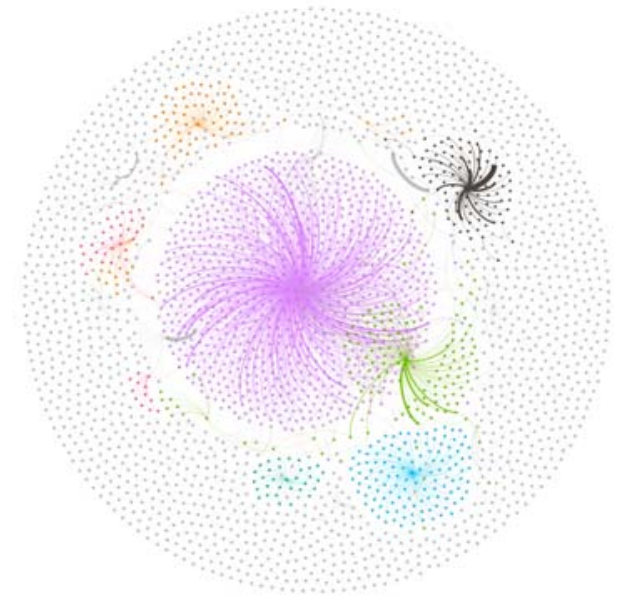

Gbr. 3 Jaringan Sosial Tokopedia

Hasil pemodelan yang menggambarkan jaringan sosial yang terbentuk dari interaksi user mengenai Tokopedia dapat dilihat pada gambar 3. Terlihat pada gambar node (titik) yang melambangkan aktor dan edge (garis) yang melambangkan hubungan antar aktor. Setelah melakukan pemodelan pada jaringan sosial, maka dilakukan analisis properti jaringan tersebut untuk mengetahui nilai dari jaringan sosial.

TABEL IVV

HASIL PROPERTI JARINGAN SOSIAL TOKOPEDIA

\begin{tabular}{|c|l|l|}
\hline No & \multicolumn{1}{|c|}{ Properti Jaringan } & \multicolumn{1}{c|}{ Hasil } \\
\hline 1 & Size & $\begin{array}{l}\text { Nodes: } 2903 \\
\text { Edges: } 2016\end{array}$ \\
\hline 2 & Modularity & 0,648 \\
\hline 3 & Diameter & 13 \\
\hline 4 & Average Degree & 1,389 \\
\hline 5 & Average Path Length & 3,412 \\
\hline
\end{tabular}

Pada Tabel IV, dapat dilakukan penilaian terkait jaringan sosial yang terbentuk mengenai tokopedia. Size menunjukkan jumlah komponen dalam system. Size pada jaringan sosial Tokopedia memiliki 2093 actor dan 2016 hubungan antar actor. Modularity menunjukkan bagaimana actor dapat membentuk kelompok yang berbeda-beda dalam suatu jaringan. Nilai modularity pada jaringan social Tokopedia adalah 0,648. Diameter adalah jarak terdekat antara dua nodes terjauh. Nilai diameter jaringan sosial Tokopedia adalah 13 sehingga jarak terdekat antara dua aktor terjauh pada jaringan sosial Tokopedia sebesar 13. Average degree menunjukkan derajat rata-rata dari jumlah link yang menghubungkan satu node dengan node lainnya. Nilai average degree pada jaringan social Tokopedia sebesar 1,389. Average path length diterjemahkan sebagai jumlah rata-rata akun atau node yang harus dilewati oleh suatu akun untuk mencapai akun tertentu. 
Nilai average path length pada jaringan sosial Tokopedia adalah 3,412 .

\section{Analisis Top Brand Berdasarkan Properti Jaringan}

Dari masing-masing properti jaringan pada jaringan sosial user mengenai Tokopedia dan Bukalapak dapat dilakukan perangkingan sebagai salah satu alternatif top brand. Peringkat properti jaringan antara Tokopedia dan Bukalapak dapat dilihat pada Tabel V.

TABEL V

HASIL PROPERTI JARINGAN SOSIAL TOKOPEDIA

\begin{tabular}{|c|c|c|c|c|}
\hline No & $\begin{array}{l}\text { Properti } \\
\text { Jaringan } \\
\end{array}$ & $\begin{array}{l}\text { Bukalapak } \\
\text { (B) }\end{array}$ & $\begin{array}{c}\text { Tokopedia } \\
\text { (T) }\end{array}$ & Peringkat \\
\hline 1 & Size & $\begin{array}{l}\text { Nodes : } 4040 \\
\text { Edges : } 2203\end{array}$ & $\begin{array}{l}\text { Nodes : } 2903 \\
\text { Edges : } 2016\end{array}$ & $\begin{array}{l}\text { 1. B } \\
\text { 2. T }\end{array}$ \\
\hline 2 & Modularity & 0.466 & 0.648 & $\begin{array}{l}\text { 1. } \mathrm{B} \\
\text { 2. T }\end{array}$ \\
\hline 3 & Diameter & 10 & 13 & $\begin{array}{l}\text { 1. B } \\
\text { 2. T }\end{array}$ \\
\hline 4 & $\begin{array}{l}\text { Average } \\
\text { Degree }\end{array}$ & 1.091 & 1.389 & $\begin{array}{l}\text { 1. } \mathrm{T} \\
\text { 2. } \mathrm{B}\end{array}$ \\
\hline 5 & $\begin{array}{l}\text { Average } \\
\text { Path Length }\end{array}$ & 2.999 & 3.412 & $\begin{array}{l}\text { 1. B } \\
\text { 2. T }\end{array}$ \\
\hline
\end{tabular}

Nilai properti jaringan yang pertama adalah size. Jaringan yang baik dan aktif memiliki size yang besar. Hasil data crawling (selama seminggu) menunjukkan bahwa jaringan social Bukalapak lebih memiliki size yang besar dengan actor dan hubungan yang lebih banyak.

Properti jaringan yang kedua adalah modularity. Semakin besar nilai modularity maka semakin jelas kelompok yang terbentuk. Setiap kelompok yang terbentuk dapat menjadi komunitas yang berbeda sehingga butuh spesifikasi lebih terhadap produk di setiap komunitas. Sehingga semakin kecil semakin baik yaitu pada Bukalapak dengan nilai 0,466.

Properti jaringan selanjutnya adalah diameter. Semakin kecil diameter maka akan memudahkan node untuk saling berkomunikasi karena jaraknya yang pendek. Jaringan sosial Bukalapak memiliki diameter lebih kecil yaitu sebanyak 10 dibandingkan jaringan sosial Tokopedia.

Properti jaringan yang keempat adalah average degree. Semakin banyak link (edge) yang menghubungkan antar node, maka penyebaran informasi akan semakin cepat dan mudah. Jaringan social yang memiliki average degree terbanyak akan menempati peringkat pertama yaitu Tokopedia dengan nilai average degree sebesar 1,389

Properti jaringan yang selanjutnya adalah average path length. Semakin sedikit akun yang dilewati maka semakin baik karena berarti jaringan tersebut memiliki hubungan yang kuat. Maka jaringan social Bukalapak mendapat peringkat pertama dengan nilai 2,999

\section{KESIMPULAN}

Dapat disimpulkan bahwa melalui analisis jaringan social e-commerce di media social dapat dijadikan sebagai alternatif top brand dengan melihat jaringan sosial pada media sosial Twitter. Hasil top brand dengan analisis jaringan sosial $e$ commerce disimpulkan bahwa jaringan social yang terbentuk di Twitter terkait Bukalapak lebih unggul

Untuk dapat meningkatkan size maka pihak e-commerce lebih aktif dalam melakukan tweet di Twitter dan mengajak user melakukan tweet ataupun post di Facebook terkait $e$ commerce tersebut. Untuk dapat meningkatkan nilai average degree maka perusahaan dapat mengadakan campaign dengan mengajak user untuk mention, tag temannya serta perusahaan dapat bekerja sama (follow) dengan perusahaan yang sudah memiliki followers atau friend yang banyak dan saling mengadakan campaign yang menyangkut dua perusahaan tersebut.

\section{REFERENSI}

[1] (2017) We Are Social website [Online], https://wearesocial.com/special-reports/digital-southeast-asia-2017/, tanggal akses: 25 Oktober 2017.

[2] Kenneth C. Laudon \& Carol Guercio Traver, E-commerce. Business. Technology. Society., 10th ed.., One Lake Street, Upper Saddle River, New Jersey: Pearson Education, Inc, 2014.

[3] (2016) Sharing Vision website. [Online]. https://sharingvision.com/bisnis-ecommerce-di-indonesia/, tanggal akses: 26 Oktober 2017.

[4] R. Felix, P. A. Rauschnabel, dan C. Hinsch, "Elements of Strategic Social Media Marketing: A Holistic Framework", Journal of Business Research, 2016.

[5] A. A. Alalwan, N. P. Rana, Y. K. Dwivedi, dan R. Algharabat, "Social Media in Marketing: A Review and Analysis of The Existing Literature", Journal Telematics and Informatics, 2017.

[6] M. F. Moens, J. Li, \& T. S. Chua, Mining User Generated Content. Boca Raton: CRC Press, 2014.

[7] M. Tsvetovat \& A. Kouznetsov, Social Network Analysis for Startups. Sebastopol: O'Reilly Media Inc., 2011

[8] F. Provost \& T. Fawcett, Data Science for Business, 1005 Gravenstein Highway North, Sebastopol: O'Reilly Media, Inc., 2013.

[9] W. A. Gunther, M. H. R. Mehrizi, M. Huysman, dan F. Feldberg, "Debating Big Data: A Literature Review on Realizing Value from Big Data", Journal of Strategic Information Systems, 2017.

[10] J. O'Malley \& P. V Marsden, The Analysis of Social Networks, Springer, 2008

[11] G. Cheliotis, Social Network Analysis (SNA), Singapore: National University of Singapore, 2010

[12] W. G. Zikmund, B. J. Babin, J. C. Carr dan M. Griffin, Business Research Methods. South-Western: Cengage Learning, 2009.

[13] Wireless LAN Medium Access Control (MAC) and Physical Layer (PHY) Specification, IEEE Std. 802.11, 1997. 